
the valley and delta areas: 1736 - 1756

\title{
PERFORMANCE OF DEEP WELL PNEUMATIC PUMP
}

\section{Samir Tayel $^{1}$; Zakaria Yonis ${ }^{1}$; Alaa-El-Din Elmesery ${ }^{2}$ and Adel Hasan ${ }^{3}$} ABSTRACT

The research focused on development of pumps called pneumatic. This type of pumps use compressed air to lift water. The pumping principle uses compressed air acting directly upon the surface of the liquid being pumped, maintaining an air/liquid interface. The main objectives of the present study were: Construct a simple model of pneumatic pump by available materials, evaluate some engineering parameters of pneumatic pump, draw and estimate the performance curve of pneumatic pump at lifting water (from 20 to 60m) and study of operation cost of pneumatic pump. The pneumatic pump could be double or single-acting but doubleacting is better and it consists of the main unit and assistance unit The study parameters are:- Stroke length of pump prototype were of 10,20,30, 40,50,60,70,80,90,100 cm. And water lift (pressure head) of 20, 30, 40, 50, 60 meters. At every opening position, some variables were measured as: Discharge rate, air pressure manometer, volt, ampere, full time and pulse time. The results can be summarized as:-

- $\quad$ The pump performance at stroke length of $80 \mathrm{~cm}$ for double-acting at different heads had good result for efficiency at head 20m, discharge was $0.58 \mathrm{l} / \mathrm{s}$, the consumed power for pump was $0.31 \mathrm{~kW}$, the air consumption was $3.9 \mathrm{~m} 3 \mathrm{~N}$. air/m3water and efficiency for pump was $37.11 \%$, while total efficiency was $14.65 \%$, but at head $60 \mathrm{~m}$ discharge was $0.2 \mathrm{l} / \mathrm{s}$, the consumed power for pump was $0.28 \mathrm{~kW}$, the air consumption was $7.1 \mathrm{~m} 3 \mathrm{~N}$. air/m3water and efficiency for pump was $42.55 \%$, while total efficiency was $13.78 \%$.

- $\quad$ The results show that total cost $=0.453 \mathrm{~L}$. E/h and the total cost of lifting water at different pump lifts was $0.22 \mathrm{L.E} / \mathrm{m}^{3}$ at $20 \mathrm{~m}$ lift by flow rate of $2.073 \mathrm{~m}^{3} / \mathrm{h}$ and $0.63 \mathrm{L.E} / \mathrm{m} 3$ at $60 \mathrm{~m}$ lift by flow rate of 0.719 $\mathrm{m}^{3} / \mathrm{h}$.

\footnotetext{
${ }^{1}$ Prof. emerit of Agric. Eng.; Faulty of Agric.; (Cairo) Al-Azhar Uni.

${ }^{2}$ Assoc. Prof. of Agric. Eng.; Faulty of Agric.; (Cairo) Al-Azhar Uni.

${ }^{3}$ Post graduate student of Agric. Eng.; Dept. Faulty of Agric.; Al-Azhar Uni.
}

The $17^{\text {th }}$. Annual Conference of the Misr Society of Ag. Eng., 28 October, $2010 \quad-1736$ - 


\section{INTRODUCTION}

$\mathrm{D}$ eep well turbine pump (vertical and submersible) is important part of the new farm, especially in desert areas where water is deep. This type of pumps make rapid progress in the desert, where it has proved success in lifting of water from beneath the ground (Hansen et al., 1980). Deep well turbine pumps must have correct alignment between the pump and the power unit. It is very important that the well is straight. The pump column assembly must be vertically aligned so that no part touches the well casing. Spacers are usually attached to the pump column to prevent the pump assembly from touching the well casing. If the pump column does touch the well casing, vibration will wear holes in the casing. A pump column out of vertical alignment may also cause excessive bearing wear. speed of diesel engine during the operation must be set so that the pump is far from the critical speed (scherer, 1993 and Addison, 1948). This research will study an alternative(assistant) to lifting water from wells without moving parts because all the problems of the vertical turbine pump is by mechanical movement. Therefore, the research focused on the type of pump called pneumatic pump. This type of pumps uses compressed air to lift water. The pumping principle uses compressed air acting directly upon the surface of the liquid being pumped. Cherkassky (1985) mentioned that the pumps con be classified as positive displacement pump, Jet pump, Dynamic pump, Pneumatic pump. He said that liquids are sometimes raised and transported by pneumatic lifts using compressed air or commercial gas. The pneumatic facilities of metal-working and machine building plants are normally supplied with compressed air from reciprocating or more rarely rotary compressors.

The pneumatic pump may have some advantages as follows:

1. This pump works without moving parts: no shaft, no bearings and no impeller.

2. It lifts water with sand without any problems.

3. Simple design - it can be manufactured by small workshops and easy for repairing and maintenance by the farmers themselves.

4. The initial cost is less than the turbine pump. 
5. The initial cost was low because simple installation, and manufactured by local materials.

6. There is a large degree of flexibility in the use of the driving force. (RMS Enviro Solv Inc. Pitbull pumps)

The main objectives of the present study were as follows:-

1. Construct a simple model of pneumatic pump by available materials.

2. Evaluate some engineering parameters of pneumatic pump.

3. Draw and estimate the performance curve of pneumatic pump at lifting water (from 20 to $60 \mathrm{~m}$ ).

4. Study of operation cost of pneumatic pump.

\section{MATERIALS AND METHODS}

\section{Materials.}

\section{Laboratory prototype.}

Laboratory prototype pneumatic pump (single acting and double acting) were constructed tested and evaluated at Agriculture Engineering Department Faculty of Agriculture, El Azhar University using local materials.

\section{1- Single acting Prototype.}

Single acting Prototype components are as shown in fig. (1)

\subsection{1- Pump chamber.}

Pump chamber consists of:

1. PVC (polyvinyl chloride) pipe, $10 \mathrm{bar}$, internal diameter of $100 \mathrm{~mm}$ and length of $1125 \mathrm{~mm}$, including entrance and exit holes at the bottom of the pipe.

2. The entrance hole is connected by check valves ( 2 inches) to allow water to enter the pipe but not allowed to leave.

3. Also, the exit hole is connected by check valves ( 2 inches) to allow water to leave the chamber but not allowed to enter.

4. The entrance hole is connected by basin 200 liters that feeds the chamber by water by pipe filling. The head of the basin equals (2metter) above the entrance valve.

5. The discharge tube is connected by the exit hole.

6 . The air valves group connected by the pipe from the top.

7. There are two sensors(censor 1 and censor 2) inside the chamber to control liquid level inside it. 


\subsection{2- The air valves group.}

The air valves group consists of:

A. The air inlet valve: this allows compressed air to enter the pump chamber.

B. The air escape valve: this allows air exhaust to exit from the pump chamber. As a result, the fluid moves to the surface.

\section{The air escape valve consists of:}

B.1 Air valve allows compressed air to enter the diaphragm chamber to press on diaphragm in order to close the air exhaust exit hole. This hole has diameter $50 \mathrm{~mm}$.

B.2 Air valve allows compressed air to exit from the diaphragm chamber in order to open air escape hole as this design for the air exhaust valve in order to expedite the process of filling.

- Air valve (solenoid valve).

\subsection{3- Control unit.}

The control unit is the head of the pump and which controls the entrance and escape of air to the pump chamber by the air solenoid valves group. Control unit consists of contactor which receives the reference electric signal from the sensor, after that changes opening or closing the valves as will be explained later.

\section{Control unit consists of:}

1-contactor , 2-two sensors and 3-three air solenoid valves

\section{2- Double acting Prototype.}

Components of double acting prototype are as shown in fig. (2). Double acting prototype consists of: single acting prototype (the main unit) and assistance unit.

\section{Assistance unit consists of:}

(Pump chamber) PVC pipe 10 bar (pipe2) internal diameter of $100 \mathrm{~mm}$ and length of $600 \mathrm{~mm}$. It includes entrance and exit hole at the bottom of the pipe. Length of the assistance unit is less than the length of the main unit, because the unit time of unloading assistance is equivalent to the time of filling the main unit, and the time of filling the main unit is equivalent to half the time to empty the main unit. Therefore, the length of assistance unit is equivalent to half the length of the main unit. 


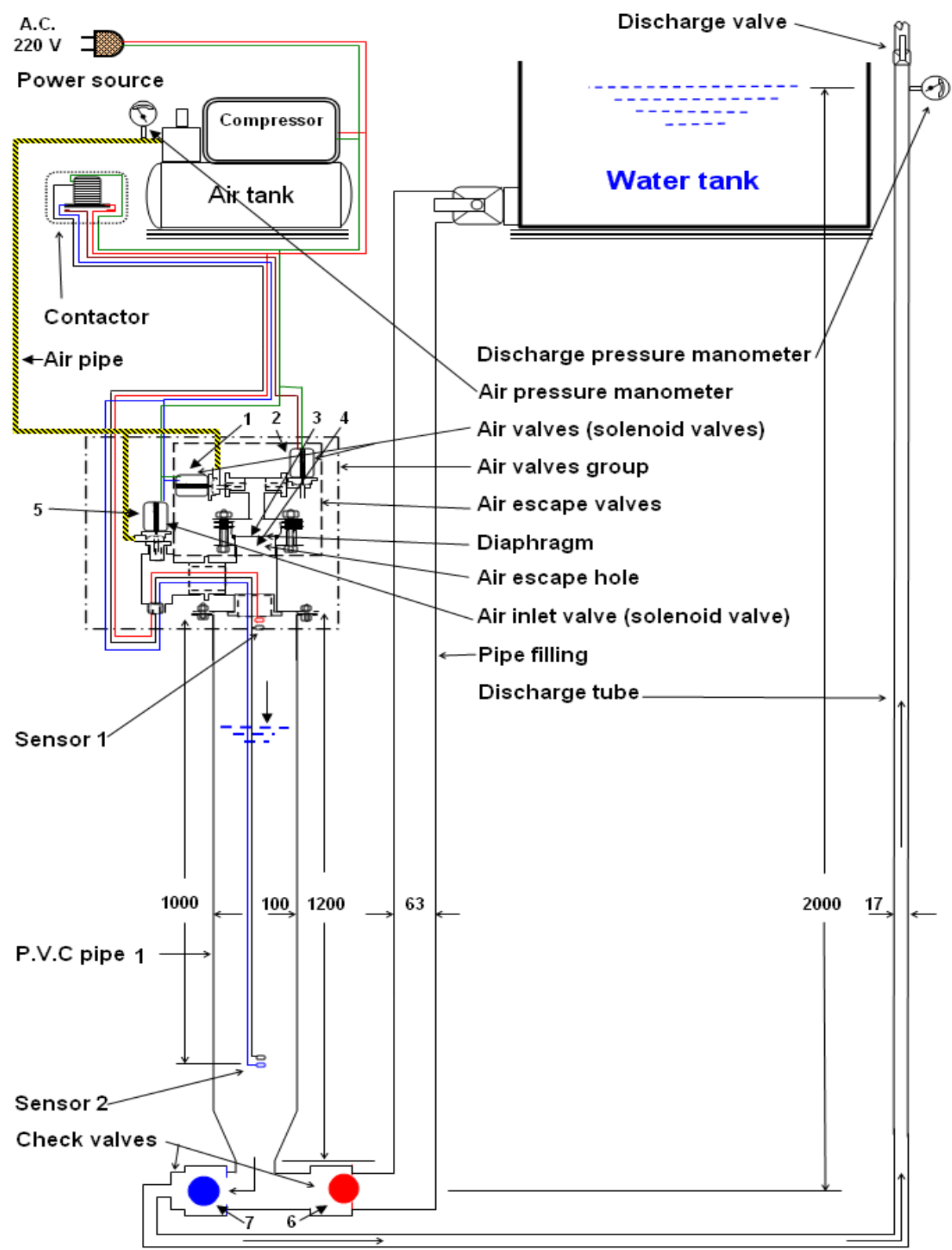

Fig.(1):Single acting prototype pneumatic at discharge cycle. Dime. $\mathbf{m m}$ (Hasan, 2007). 


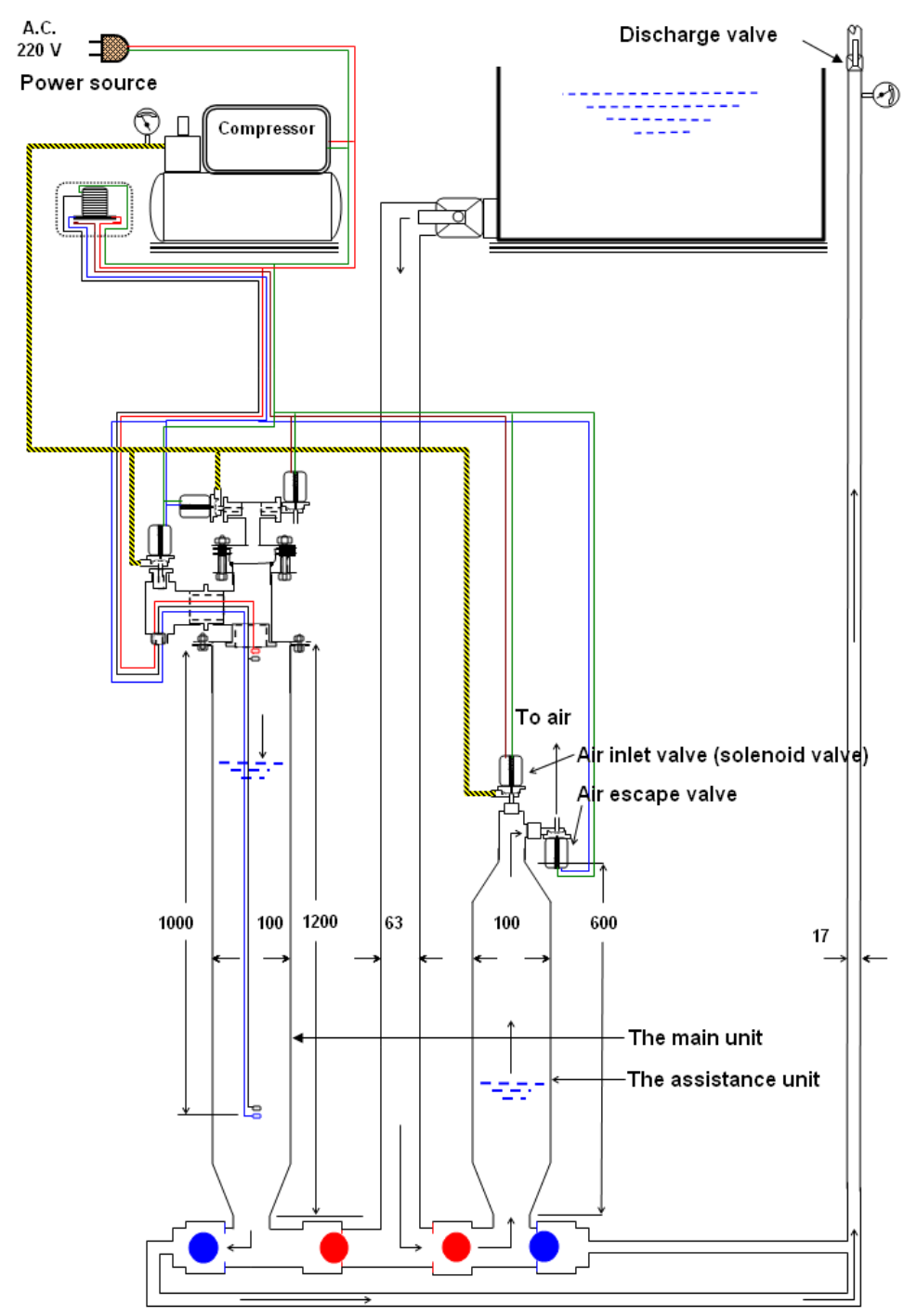

Fig. (2): Double acting prototype pneumatic pump. Dime. mm(Hasan, 2007).

\subsection{How prototype pneumatic pump works (single acting).}

As shown in fig. (1), when fluid level in the pump chamber touches upper sensor (sensor (1)), when filling, the controls automatically close the air escape valve [ by opening valve (1) and close valve (2) diaphragm (3) closes air escape hole (4)] and also the controls automatically open the air inlet valve (5) [air discharge from compressor] releasing 
compressed air energy into the top of the pumping chamber and on the liquid surface. The inlet check valve (6) is automatically pushed closed. Liquid is forced out through the now open discharge check valve (7) and connected piping. When fluid level in the pump chamber touches lower sensor (sensor 2), when unloading, the controls automatically close the air inlet valve (5) and open the air escape valve (by closing valve (1) and opening valve (2) diaphragm (3) opens air escape hole (4)). To replace the water instead of air and start a new cycle. After each discharge cycle, the air is automatically shut off and the filling and discharge cycle is repeated. (This discharge pulses).

\subsection{How prototype pneumatic pump works (double acting).}

As shown in fig. (2), when the assistance unit is operated with the main unit, the discharge continues. At the same time, filling the main unit, the assistance unit is empty because the assistance unit takes the reference electricity from the main unit. When closing the air inlet valve (5) at the main unit, the air inlet valve at the assistance unit is opened and air escape valve at the assistance unit is closed.

\section{Methods}

\subsection{Test procedure and instrumentation:}

The prototype was tested using the test rigging and measuring instruments as indicated in figure (2). The following test procedures were done:

- Single acting prototype and double acting prototype were operated at different stroke lengths of pump (10, 20, 30, 40, 50, 60, 70, 80, 90, $100 \mathrm{~cm}$ ) by changing the distance between the sensors (sensor 1 and sensor 2).

- Every pump stroke length was operated at different pressure heads (20, 30, 40, 50, 60 meters) adjusted on delivery pipe as shown in fig. (2) by changing of opening discharge valve.

- At every opening position, six variables were measured: delivery pressure, air pressure, volt, amber, discharge rate, and cycle time, pulse time and full time.

The instruments employed to measure discharge, head, volt, ampere and cycle time are listed in table (1). 
Table (1):The used instruments for measuring the test variables.

\begin{tabular}{|c|c|}
\hline Measurement item & Instrument \\
\hline Discharge & Calibrated bucket and stopwatch \\
\hline Head and stroke length & Manometer and steel tap \\
\hline Volt and ampere & Clamp avometer \\
\hline
\end{tabular}

\subsection{Theoretical study:}

\subsection{1- Calculated pump efficiency.}

The power input to compressor shaft was calculated by the following equations: (Cherkassky, 1985)

$$
N_{\text {inputcompressor }}=P_{1} V_{1}\left(\ln \frac{P_{2}}{P_{1}}\right)\left(\frac{1}{\eta_{\text {iso. }} \eta_{m}}\right)
$$

Where:

$N_{\text {comp }}=$ the power input to the compressor shaft(w), $P_{l}=$ atmospheric pressure $(\mathrm{Pa}), V_{l}=$ initial volume $\left(\mathrm{m}^{3} / \mathrm{s}\right), p_{2}=$ compressor pressure $(\mathrm{Pa}), \eta_{\text {ise }}$ $=$ isothermal efficiency assuming $(0.7), \eta_{m}=$ mechanical efficiency assuming (0.8).

$$
N_{\text {electrical }}=P_{1} V_{1}\left(\ln \frac{P_{2}}{P_{1}}\right)\left(\frac{1}{\eta_{\text {iso. }} \eta_{m} \eta_{\text {motor }} \eta_{\text {drive }}}\right)
$$

Where: $\mathrm{N}_{\text {electrica }}=$ electrical power consumption by compressor engine $(w), \eta_{\text {motor }}=$ motor efficiency assuming $(0.8), \eta_{\text {drive }}=$ ratio of power to when the shaft of the motor and compressor are connected directly(1).

$$
N_{\text {outputcomp. }}=P_{1} V_{1}\left(\ln \frac{P_{2}}{P_{1}}\right)
$$

From formulas 1,2 , and 3

$$
\begin{aligned}
& N_{\text {pump }}=P_{1} V_{1}\left(\ln \frac{P_{2}}{P_{1}}\right)=N_{\text {electrical }} \times\left(\eta_{\text {iso }} \eta_{M} \eta_{\text {motor }} \eta_{\text {drive }}\right) \\
& N_{\text {Hydraulic }}=Q \rho g h
\end{aligned}
$$

Where: $\mathrm{Q}=$ Discharge $\mathrm{m}^{3} / \mathrm{s}, \rho=$ Density $\mathrm{kg} / \mathrm{m}^{3}, \mathrm{~g}=$ gravitational acceleration $\mathrm{m} / \mathrm{s}^{2,} \mathrm{~h}=$ Head $\mathrm{m}$. 


$$
\eta_{\text {Pump }}=\frac{N_{\text {Hydraulic }} \times 100}{N_{\text {Pump }}}
$$

Where: $\eta_{\text {Pump }}$ Pump efficiency $\%, \mathrm{~N}_{\text {Hydraulic }}=$ The hydraulic power $(\mathrm{w})$, $\mathrm{N}_{\text {Pump= }}$ The input power for pump (w).

\subsection{2- Calculating of the consumed air (SCMS).}

The consumed air (SCMS) is for standard cubic meters per second: a measure of flow of free air, at (standard temperature $\left(25^{\circ} \mathrm{C}\right)$ and standard pressure $(101.325 \mathrm{kPa})=\left(\right.$ normal $\left.\mathrm{m}^{3} / \mathrm{s}\right)$ The consumer air required to drive the pump is calculated by the following formula .

$$
V_{1}=\frac{P_{2} \times V_{2}}{P_{1}} \ldots \ldots \ldots \ldots \text { (7) }
$$

Where: $V_{1}=$ Initial volume $\left(\mathrm{m}^{3} / \mathrm{s}\right), \mathrm{P}_{2}=$ Compressor pressure $=$ the pressure above the water's surface inside the pump room, $\mathrm{V}_{2}$ = The volume of air under pressure $\mathrm{P} 2\left(\mathrm{~m}^{3} / \mathrm{s}\right)$.

in order to determine $\mathrm{V}_{1}$, assume that:

- $\mathrm{V}_{2}$ equals the same volume of water into the pump chamber. (because the air replaces the water)

- $\mathrm{P}_{1}=$ atmospheric pressure $(\mathrm{Pa})$

- Temperature $\mathrm{V}_{2}=$ temperature of $\mathrm{V}_{1}$ approx.

So, it is possible to calculate the volume of air $\left(\mathrm{V}_{1}\right)$ by equation (7) by using the volume of water (discharge) outside of the pump equal to $\left(\mathrm{V}_{2}\right)$. So from equation (2)

$$
\therefore V_{1}=\frac{N_{\text {elect. }} \times\left(\eta_{\text {iso }} \eta_{M} \eta_{\text {motor }} \eta_{\text {drive }}\right)}{P_{1}\left(\ln \frac{P_{2}}{P_{1}}\right)}
$$

and using equations (7) \&(8)

$$
\therefore V_{1}=\frac{P_{2} \times V_{2}}{P_{1}}=\frac{N_{\text {elect. }} \times\left(\eta_{\text {iso }} \eta_{M} \eta_{\text {motor }} \eta_{\text {drive }}\right)}{P_{1}\left(\ln \frac{P_{2}}{P_{1}}\right)} .
$$

Where: $\quad \mathrm{V}_{1}=$ SCMS (standard cubic meters per second) For calculated

$\eta_{\text {total for compressor from equation (9) }}$

$$
\eta_{\text {total, for, } \text { comp. }}=\left(\eta_{\text {iso }} \eta_{M} \eta_{\text {motor }} \eta_{\text {drive }}\right)=\frac{P_{1}\left(\frac{P_{2} \times V_{2}}{P_{1}}\right)\left(\ln \frac{P_{2}}{P_{1}}\right)}{N_{\text {elect. }}}
$$




$$
\therefore \eta_{\text {total, for,comp. }}=\left(\eta_{\text {iso }} \eta_{M} \eta_{\text {motor }} \eta_{\text {drive }}\right)=\frac{\left(P_{2} \times V_{2}\right)\left(\ln \frac{P_{2}}{P_{1}}\right)}{N_{\text {elect. }}}
$$

Therefore,

$\mathrm{P} 2$ = the pressure measured on the surface of the water (Inside the pump chamber above water's surface)

$\mathrm{V} 2=$ the volume of water (discharge) outside of the pump. $\left(\mathrm{m}^{3} / \mathrm{s}\right)$

$$
\begin{gathered}
N_{\text {pump }}=N_{\text {elect. }}\left(\eta_{\text {total }}\right) \\
N_{\text {pump }}=(\text { volt } \times \text { amber } \times \cos . \theta)\left(\eta_{\text {iso }} \eta_{M} \eta_{\text {motor }} \eta_{\text {drive }}\right)
\end{gathered}
$$

Determining. Specific power.

$$
\text { Specific _ power }=\frac{N_{\text {pump }}(k w)}{\text { Distch } \arg e(l / s)}=(k w /(l / s))
$$

\section{Determining volume of air required per cubic meters of water pumped.}

Specific air consumption $=\frac{\text { air_consumption }\left(\frac{M^{3}}{h}\right)}{\operatorname{Disch} \arg e\left(\frac{M^{3}}{h}\right)}$

\subsubsection{Cost analysis:}

The machinery costs included both the fixed costs and operating costs.

1. Fixed costs

i. Depreciation

$$
D=\frac{(P-S)}{I}
$$

ii. Interest

$$
L=\left[\frac{(P+S)}{2}\right] \times i
$$

iii. Taxes, housing, and insurance can be estimated as percentage of the purchase price $(2 \%)$. 
2. Operating costs

i. Repair and maintenance

ii. Fuel

$$
T A R=0.015 e^{0.297} X
$$

$$
F=F_{c} \times C_{F}
$$

iii. Lubrication

$$
\text { Lub. }=0.15 F
$$

iv. Labor

$$
\text { Labor }_{-} f e e=8\left(\frac{L . E}{d a y}\right)
$$

Where: $\mathrm{D}=$ Depreciation (L.E/yr.), $\mathrm{P}=$ Purchase price (L.E), S=Salvage price (L.E), I=Expectancy life (yr.), L=Interest (L.E/yr.), i=Rate of interest (\%), TAR=Total accumulated repair costs expressed as a percent of purchase price, $\mathrm{X}=$ Thousand hours of accumulated use(h), F= Fuel $\operatorname{cost}(\mathrm{L} . \mathrm{E} / \mathrm{h}), \mathrm{F}_{\mathrm{c}}=$ Fuel consumption (litter/h), $\mathrm{C}_{\mathrm{F}}=$ Cost of fuel (L.E/litter).

\section{RESULTS AND DISCUSSION}

\section{Effect of pump lift (H) on pump discharge at different stroke} lengths of pump (double-acting pump and single-acting pump)

\subsection{Double-acting pump:}

Fig. (3) shows the relation between pump lift and pump discharge "L/s" at different stroke lengths of pump. The data show that the discharge was decreased with the increase of pump lift from $0.49 \mathrm{l} / \mathrm{s}$ to $0.17 \mathrm{l} / \mathrm{s}$ at pump lift of 20 to $60 \mathrm{~m}$ and pump stroke length of $10 \mathrm{~cm}$ and $0.54 \mathrm{l} / \mathrm{s}$ to $0.19 \mathrm{l} / \mathrm{s}$ at pump lift of 20 to $60 \mathrm{~m}$ and pump stroke length of $100 \mathrm{~cm}$. Also, the highest discharge was of $0.58 \mathrm{l} / \mathrm{s}$ at pump lift $20 \mathrm{~m}$ and pump stroke length of $80 \mathrm{~cm}$. The highest discharge, at stroke length of $80 \mathrm{~cm}$ may be attributed to compressor power.

\subsection{Single-acting pump:}

Fig. (4) shows the relation between pump lift. and pump discharge "L/s" at different stroke length of pump. The data show that the discharge was decreased with the increase of pump lift from $0.46 \mathrm{l} / \mathrm{s}$ to $0.16 \mathrm{l} / \mathrm{s}$ at pump lift of 20 to $60 \mathrm{~m}$ at pump stroke length of $10 \mathrm{~cm}$ and $0.52 \mathrm{l} / \mathrm{s}$ to $0.18 \mathrm{l} / \mathrm{s}$ at pump lift of 20 to $60 \mathrm{~m}$ at pump stroke length of $100 \mathrm{~cm}$. 

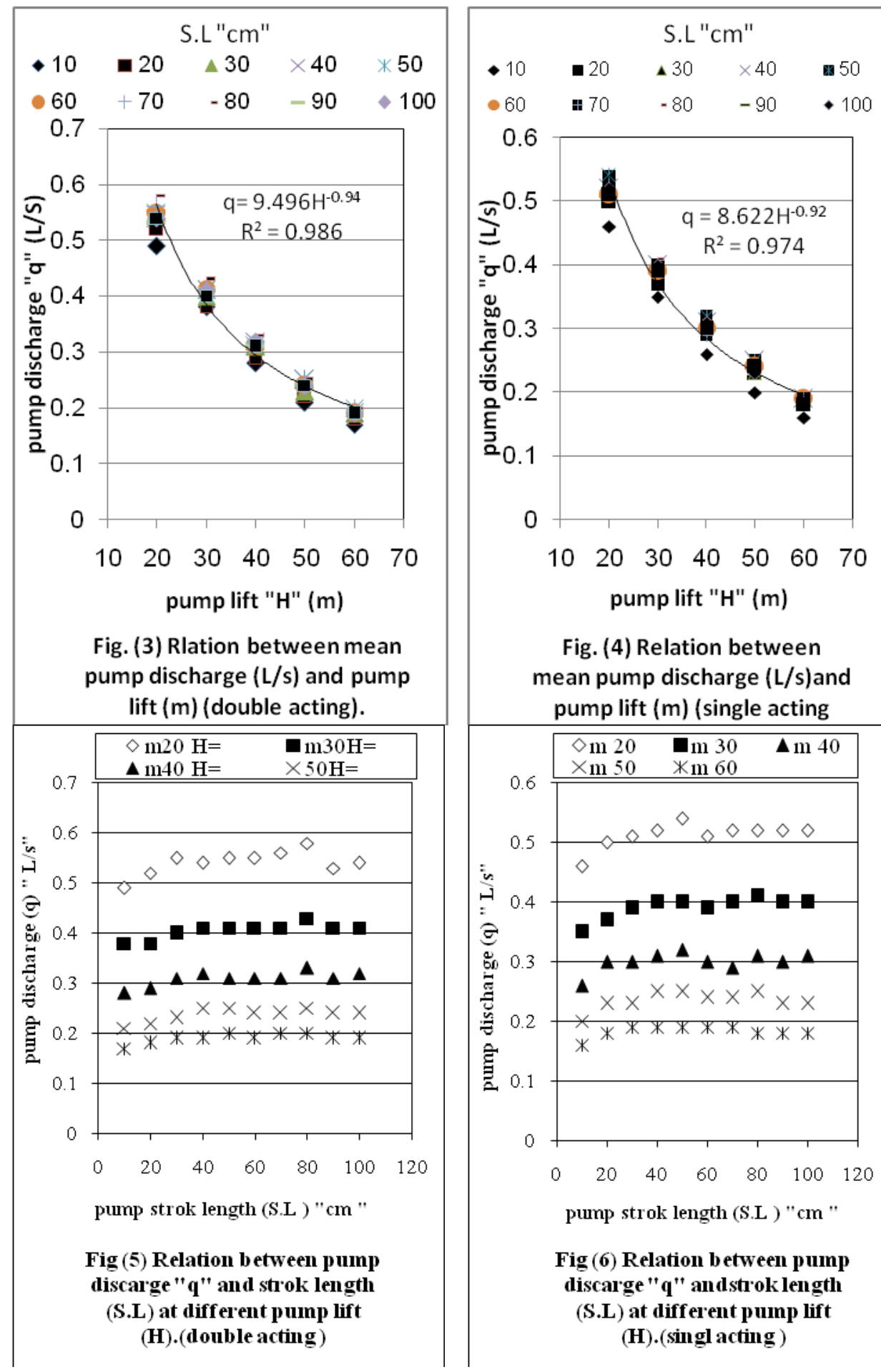

Fig. (4) Relation between mean pump discharge (L/s)and pump lift $(m)$ (single acting

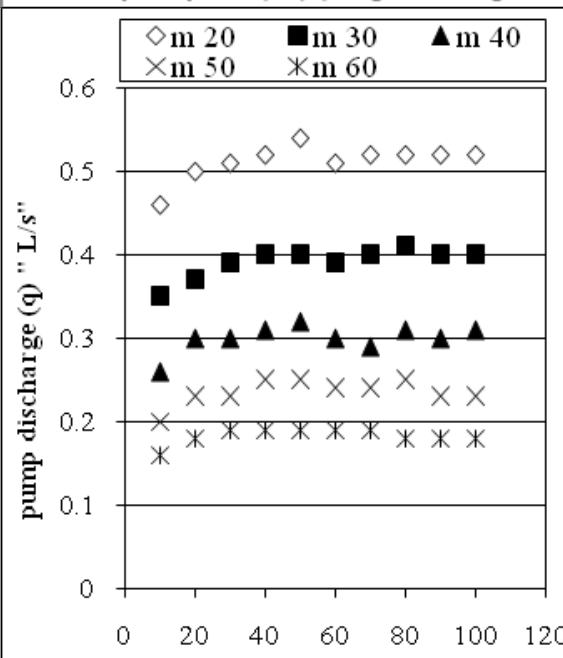
pump strok length (S.L ) " $\mathrm{cm}$ "

Fig (6) Relation b etween pump discarge " $q$ " andstrok length (S.L) at different pump lift (H). (singl acting ) 
Also the highest discharge was $0.54 \mathrm{l} / \mathrm{s}$ at pump lift of $20 \mathrm{~m}$ and pump stroke length of $50 \mathrm{~cm}$. The highest discharge at stroke length of $50 \mathrm{~cm}$ is the ideal stroke length with the compressor power.

Generally, this means that using stroke length pump from 50 to $80 \mathrm{~cm}$ (double-acting) gave the best condition, compared with using any stroke length double-acting or single-acting. Discharge increased by increasing stroke length until $80 \mathrm{~cm}$, after that the increase of discharge was stopped. This result may be attributed to capacity of compressor. The highest discharge was obviously produced using double-acting pump compared with single-acting pump. The increase in discharge was lowest by increasing pump lift.

\section{Effect of stroke length of pump (S.L) on pump discharge at different heads $(\mathrm{H})$ (for double and single acting pumps)}

\subsection{Double-acting pump:}

Fig. (5) indicate that the mean discharge was $0.54 \mathrm{l} / \mathrm{s}$ and $(\mathrm{CV}=4.24 \%)$ at pump lift of $20 \mathrm{~m}$ for all stroke lengthes. Also, the mean discharge was $0.19 \mathrm{l} / \mathrm{s}$ and $(\mathrm{CV}=4.93 \%)$ at pump lift of $60 \mathrm{~m}$ with each stroke length.

\subsection{Single-acting pump:}

Fig. (6) indicate that the mean discharge was $(0.51 \mathrm{l} / \mathrm{s})$ and CV. (4.02) at pump lift of $20 \mathrm{~m}$. Also, the mean discharge was $0.18 \mathrm{l} / \mathrm{s}$ and $(\mathrm{CV}=$ $4.99 \%$ ) at pump lift of $60 \mathrm{~m}$ at different stroke lengths . These results indicate that the stroke length does not affected on discharge at this case, but may affect at different cases.

\section{Effect of stroke length of pump (S.L) and pump lift (H) on pump total efficiency $" \eta_{\text {total }}$ ". (for double and single acting pumps)}

\subsection{Total efficiency of Double-acting pump:}

Figs. (7) shows the effect of stroke length of pump and the pump lift on pump total efficiency at different lengths of pump and different pump lifts. Data indicated that the highest values of total efficiency were $15 \%$ at stroke length (S.L) of $70 \mathrm{~cm}$ and pump lift of $20 \mathrm{~m}, 15.87 \%$ at (S.L) of $50 \mathrm{~cm}$ and $(\mathrm{H}) 30 \mathrm{~m} .15 .45 \%$ at $(\mathrm{S} . \mathrm{L}) 50 \mathrm{~cm}$ and $(\mathrm{H})$ of $40 \mathrm{~m}, 15.08$ at (S.L) of $50 \mathrm{~cm}$ and $(\mathrm{H})$ of $50 \mathrm{~m}$, and $13.86 \%$ at $(\mathrm{S} . \mathrm{L})$ of $50 \mathrm{~cm}$ and $(\mathrm{H})$ of $60 \mathrm{~m}$. Meanwhile, the lowest values were. 12.71, 13.96, 13.22, 12.43 and 11.61 $\%$ at $(\mathrm{S} . \mathrm{L})$ of $10 \mathrm{~cm}$ and $(\mathrm{H})=20,30,40,50$ and $60 \mathrm{~m}$ 


\subsection{Total efficiency of single-acting pump:}

Fig. (8) shows the effect of stroke length of pump and pump lift on pump total efficiency using different lengths of pump and different pump lifts. Data indicated that the highest values of total efficiency were $13.92 \%$ at stroke length (S.L) $90 \mathrm{~cm}$ and pump lift of $20 \mathrm{~m}, 15.51 \%$ at (S.L) of $80 \mathrm{~cm}$ and $(\mathrm{H})$ of $30 \mathrm{~m} ., 15.34 \%$ at $(\mathrm{S} . \mathrm{L})$ of $50 \mathrm{~cm}$ and $(\mathrm{H})$ of $40 \mathrm{~m}, 14.75$ at (S.L) of $80 \mathrm{~cm}$ and $(\mathrm{H})$ of $50 \mathrm{~m}$ and $13.55 \%$ at $(\mathrm{S} . \mathrm{L})$ of $50 \mathrm{~cm}$ and $(\mathrm{H})$ of $60 \mathrm{~m}$. Meanwhile, the lowest values were. 11.61, 12.73, 12.65, 12.01 and 11.35 $\%$ at (S.L) of $10 \mathrm{~cm}$ and $(\mathrm{H})$ of $20,30,40,50,60 \mathrm{~m}$. The results mean that: using stroke length from 50 to $80 \mathrm{~cm}$ (double-acting) gave the best condition for increasing total efficiency compared with using other (S.L) (double-acting or single-acting ). Total efficiency increased by increasing stroke length until 50 to $80 \mathrm{~cm}$. The highest total efficiency was produced using double-acting pump compared with single-acting pump.

\section{Effect of stroke length of pump (S.L) on pulse volume at different pump lifts "H"}

Fig. (9) shows the relation between stroke length of pump (S.L) "cm" and pulse volume of pump at different pump lifts. The results indicated that the pulse volume is constant at different pump lifts at all stroke lengths. Fig. (9): reveal that the pulse volume increased with the increase of stroke length.

\section{The air consumption and the consumed power:}

Fig. (10) shows the consumed power for compressor engine and the specific air consumption at different heads and discharges for (pump length $80 \mathrm{~cm}$ double-acting) only which has good discharge. Also its shows that the air consumption for all discharges and consumed powers increased whenever the pump lift increased.

\section{Pump performance curve}

Table (2) shows the pump performance at pump length of $80 \mathrm{~cm}$ for double-acting at different heads and discharges with good results in discharge. Fig. (11) shows relationship between discharge "L/s" and head "m", efficiency "\%", power "kw" and air consump." $\mathrm{m}^{3}$ N. air $/ \mathrm{m}^{3}$ water" 

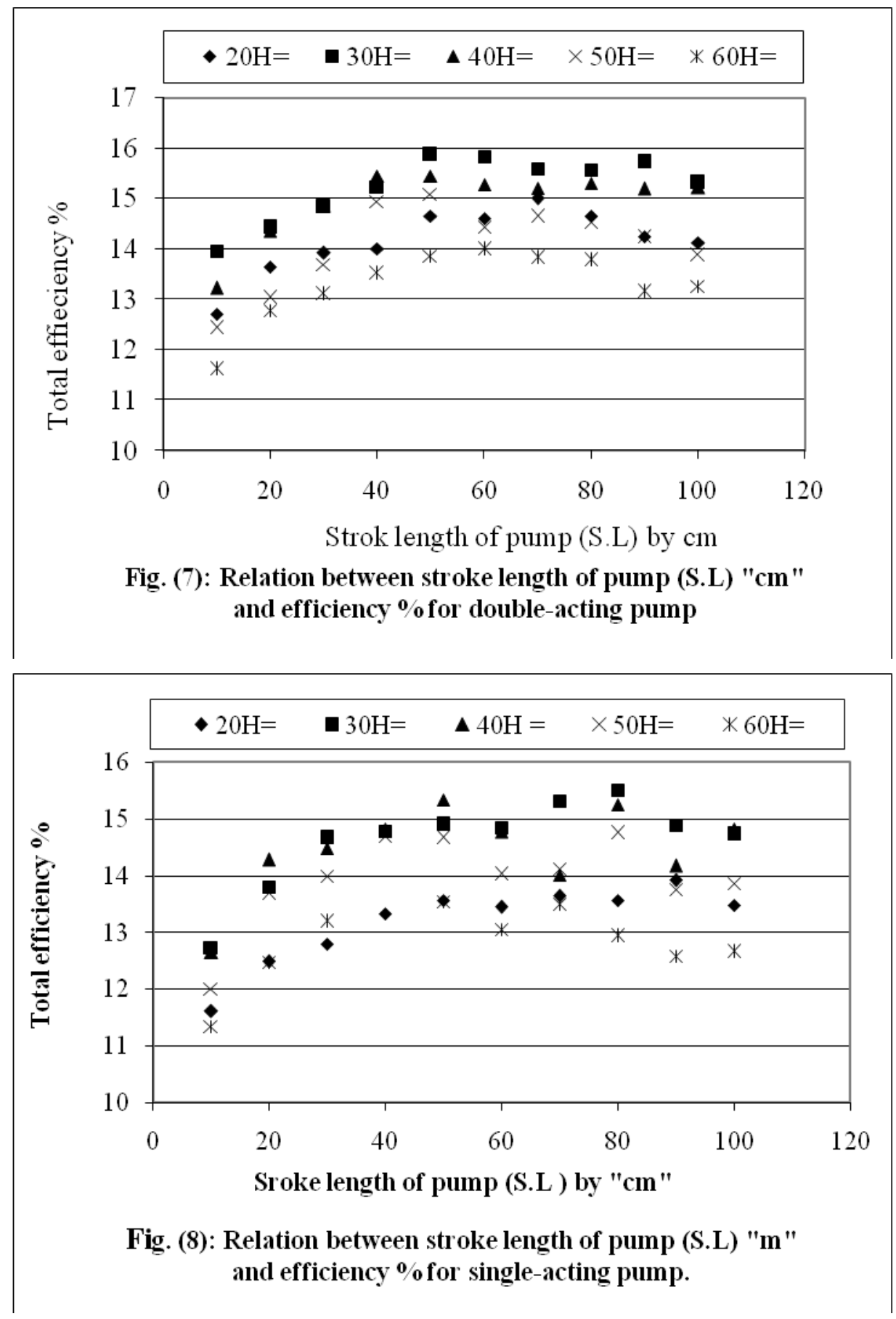

The $17^{\text {th }}$. Annual Conference of the Misr Society of Ag. Eng., 28 October, $2010 \quad-1750-$ 

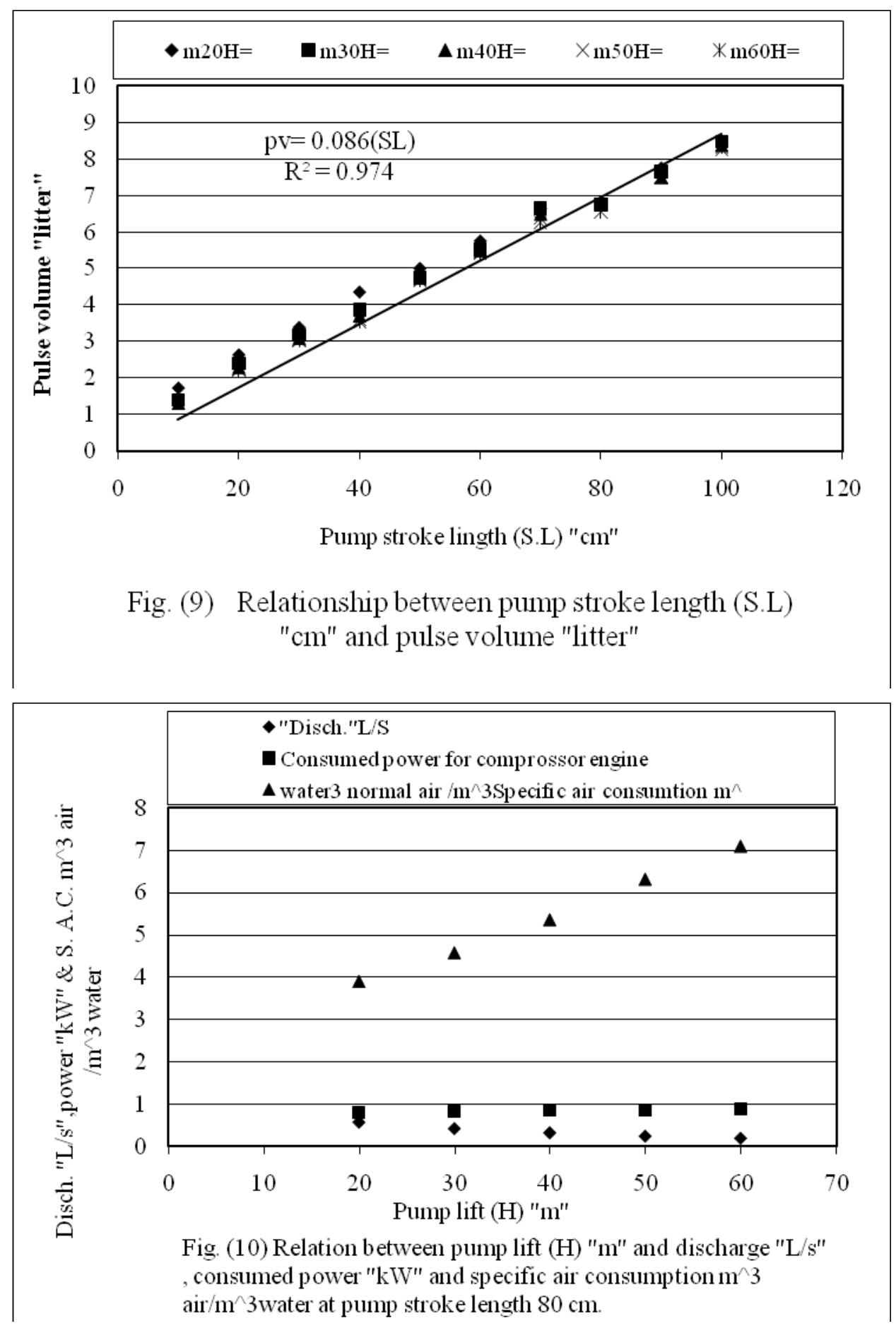

The $17^{\text {th }}$. Annual Conference of the Misr Society of Ag. Eng., 28 October, $2010 \quad-1751-$ 


\section{Cost analysis:}

The total cost per hour for the pneumatic pump is calculated according to the procedure previously given in section 3.2.3.as follows:

$\mathrm{P} \quad=1400$ (compressor $=800 \mathrm{LE} \& \mathrm{Pump}=600 \mathrm{LE})$ (L.E)

$\mathrm{S}=140$

$1=5$

$\mathrm{i}=10$

$\mathrm{x}=1$

$\mathrm{F}_{\mathrm{c}}=0.836$

$\mathrm{C}_{\mathrm{KW}}=0.07$

(L.E/(KW/h))

Table (2):Pump performance at pump length $80 \mathrm{~cm}$ for double-acting

\begin{tabular}{|c|c|c|c|c|}
\hline $\begin{array}{c}\text { Disch. } \\
\text { "L/s" }\end{array}$ & $\begin{array}{c}\text { Head } \\
\text { "m" }\end{array}$ & $\begin{array}{c}\eta_{\text {pump }} \\
\text { "\%" }\end{array}$ & Power "kw" & $\mathrm{m}^{3}{ }_{\text {N. air }} / \mathrm{m}^{3}$ water \\
\hline 0.58 & 20 & 37.11 & 0.3103 & 3.9 \\
\hline 0.43 & 30 & 42.45 & 0.3005 & 4.58 \\
\hline 0.33 & 40 & 43.91 & 0.2972 & 5.36 \\
\hline 0.25 & 50 & 42.3 & 0.29308 & 6.32 \\
\hline 0.20 & 60 & 42.55 & 0.28159 & 7.1 \\
\hline
\end{tabular}

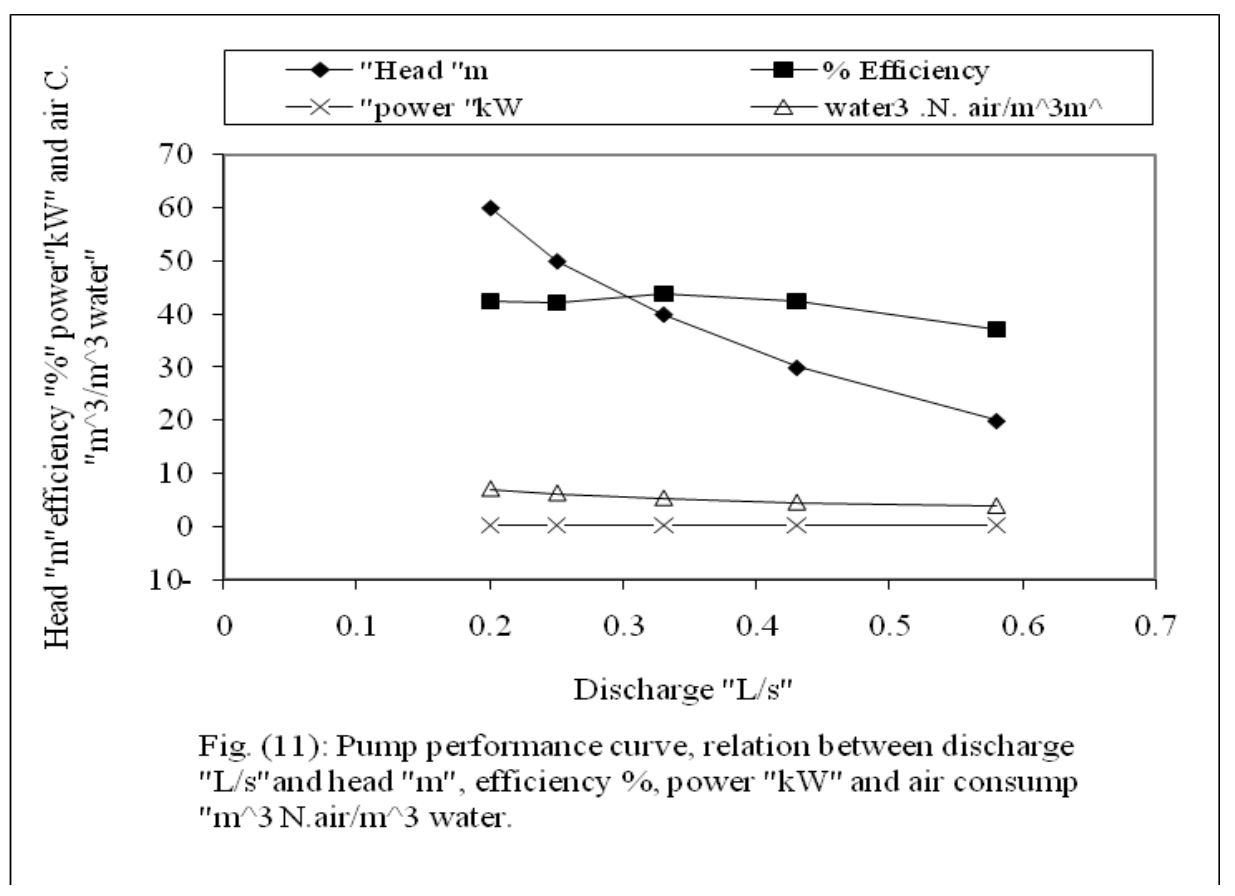

The $17^{\text {th }}$. Annual Conference of the Misr Society of Ag. Eng., 28 October, $2010 \quad-1752-$ 
Total cost of lifting water per cubic meter is calculated as follows:

Total cost of lifting of $1 \mathrm{~m}^{3}$ water $\left(\mathrm{L} . \mathrm{E} / \mathrm{m}^{3}\right)=$ total costs per hour $(\mathrm{L} . \mathrm{E} / \mathrm{h})$ discharge $\left(\mathrm{m}^{3} / \mathrm{h}\right)$ at different heads. Table (3) and fig. (12) show the total costs of lifting $1 \mathrm{~m}^{3}$ of water $\left(\mathrm{L} . \mathrm{E} / \mathrm{m}^{3}\right)$ at different heads.

Table (3):Total cost of lifting $1 \mathrm{~m}^{3}$ of water $\left(\mathrm{L} . \mathrm{E} / \mathrm{m}^{3}\right)$ at different heads.

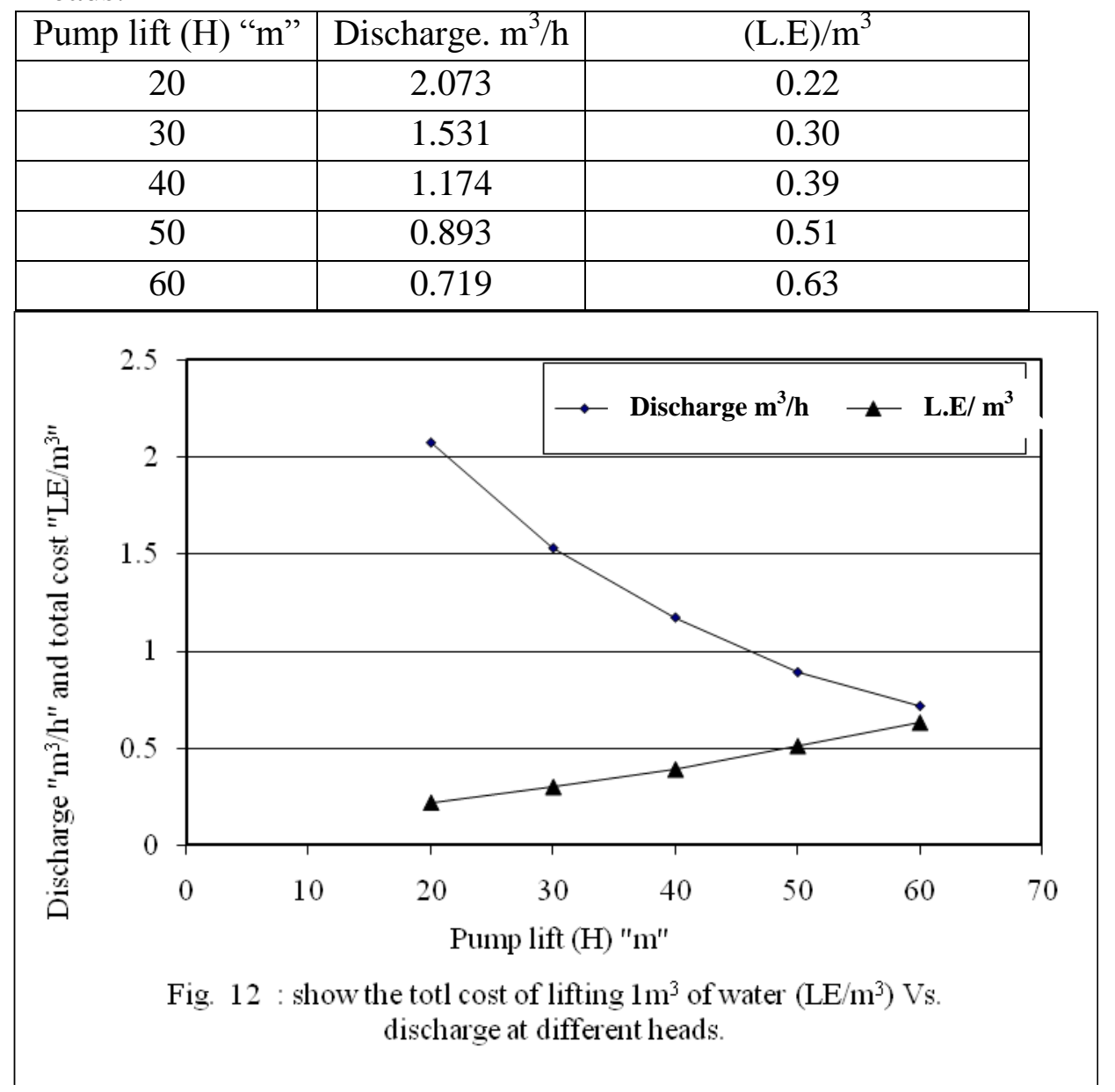

\section{SUMMARY AND CONCLUSION}

The research focused on development of pumps called pneumatic. This type of pumps use compressed air to lift water. The pumping principle uses compressed air acting directly upon the surface of the liquid being pumped, maintaining an air/liquid interface. The obtained results of the 
experimental work can be summarized and concluded in the following points:-

- Using stroke length of pump from 50 to $80 \mathrm{~cm}$ (double-acting) gave the best condition for increasing discharge, compared with using any stroke length (double-acting or single-acting).

- Discharge increased by increasing stroke length until $80 \mathrm{~cm}$. This result may be attributed to capacity of compressor.

- Using stroke length of pump from 50 to $80 \mathrm{~cm}$ (double-acting) gave the best condition for increasing total efficiency compared with other stroke length (double-acting or single-acting).

- Total efficiency increased by increasing stroke length until $80 \mathrm{~cm}$.

- The highest total efficiency was produced using double-acting pump compared with single-acting pump.

- The pulse volume was constant at different pump lifts at all stroke lengths. Meanwhile the pulse volume increased with stroke length.

- The air consumption for all water volumes and consumed powers increased whenever the pump lift increased, while less discharge. The maximum air consumption $\left(7.1 \mathrm{~m}^{3}\right.$ normal air $(\mathrm{SCM}) / \mathrm{m}^{3}$ water $)$ was at pump lift of $60 \mathrm{~m}$.

- Cycle time and pulse time increased by increasing pump lift, meanwhile the full time was constant by increasing pump lift. This because pulse volume was constant by increasing pump lift.

- Cycles / minute was less by increasing pump lift.

- The pump performance at pump length of $80 \mathrm{~cm}$ for double-acting at different heads had good result for efficiency which at head of $20 \mathrm{~m}$, discharge was $0.58 \mathrm{l} / \mathrm{s}$, the consumed power for pump was $0.31 \mathrm{kw}$, the air consumption was $3.9 \mathrm{~m}^{3} \mathrm{~N}$. air $/ \mathrm{m}^{3}$ water and efficiency for pump was $37.11 \%$, while total efficiency was $14.65 \%$, but at head of $60 \mathrm{~m}$ discharge was $0.2 \mathrm{l} / \mathrm{s}$, the consumed power for pump was $0.28 \mathrm{kw}$, the air consumption was $7.1 \mathrm{~m}^{3} \mathrm{~N}$. air $/ \mathrm{m}^{3}$ water and efficiency for pump was $42.55 \%$, while total efficiency was $13.78 \%$.

- Cost analysis was made to determine the total operating cost per hour for the pneumatic pump. The results show that total cost $=$ 
0.453 (L.E/h) and the total cost of lifting water at different pump lifts was $0.22\left(\mathrm{~L} . \mathrm{E} / \mathrm{m}^{3}\right)$ at $20 \mathrm{~m}$ lift by flow rate of $2.073\left(\mathrm{~m}^{3} / \mathrm{h}\right)$ and 0.63 $\left(\mathrm{L} . \mathrm{E} / \mathrm{m}^{3}\right)$ at $60 \mathrm{~m}$ lift by flow rate of $0.719\left(\mathrm{~m}^{3} / \mathrm{h}\right)$.

The applied recommendations of the present study are as follows:-

- It is recommended that the pneumatic pump should be used for water lift, especially if there is proportion of fine sand mixed with water, because this pump works without moving parts. The unique design features include no rotating or internal parts, no bearings, no shaft and no impeller.

- It is also recommended that further experimental studying for pneumatic pump should be carried out to maximize the benefits of utilization.

\section{REFERENCES}

ASAE. 1997. Standards (44th Ed.),: 357-362. The American Society of Agricultural Engineers (ASAE). Miami. USA. C.f. Emam (2001).

Addison. H. (1948) Centrifugal and other rotodynamic pumps. Chpman\&Hall LTD.: 157-158.

Cherkassky.V. M. (1985) Pumps fans compressors. Translated from the russian by B. A. Nikolaev. Mir Publishers . Moscow.: 21:25.

Hansen. V.E; W. I Orson; E.S Glen. (1980) Irrigation principles and practices. John Wiley \& Sons. :279:280.

\section{RMS. Pitbull Pumps}

http://www.rmsenviro.com/pitbull.htm

Thomas F. Scherer,(1993) Irrigation water pumps. Extension gricultural Engineer. North Dakota State University Agriculture http.7/www.ag.ndsu.edu/pubs/ageng/irrigate/ae 1057w.htm

Hasan, A, A (2007) A study on deep well pump. M. Sc. Th., Agric Eng., Dept., Fac., of Agric., Al-azhar univ. 


\section{الملخص العربحي \\ أداء مضخات الأعماق ذات ضغط الهواء \\ سمير طايل ، زكريا يونس' ، علاء الاين المسيرى ‘ ، عادل حسنج}

تهدف هذه الدراسة إلى تطوير وتقييم مضخة الأعماق ذات ضغط الهواء و الوقوف على مدى الوى ملاءمتها لعملية الرى تحت الظروف المصرية وحيث أن مبدأ الضخ الاساسى هو استخدية الضخدام

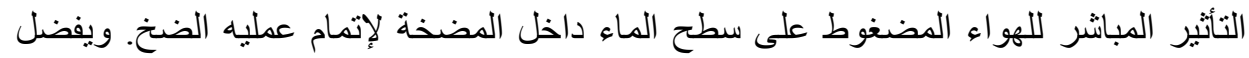
استخدام هذا النوع من المضخات لرفع الماء من الآبار التى يوجد بها الماء مختلط بنسبه من التهل

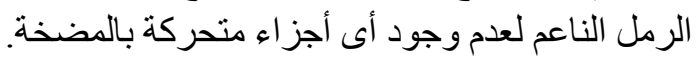
حيث اشتملت على عوامل طلمبات:-

تم بناء نماذج بسيطة لمضخة ضغط الهو اء بالمو اد المتاحة أحادية وثنائيه المفعول يعمل عند

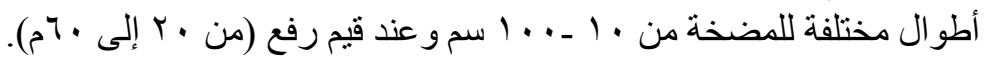

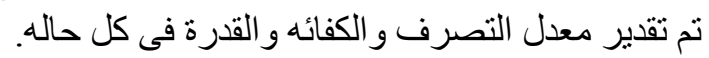

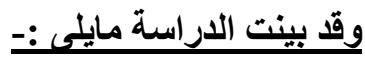

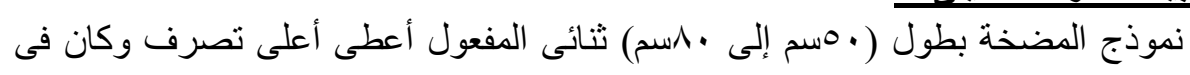

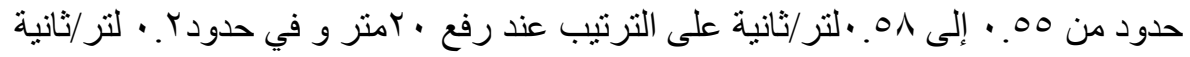

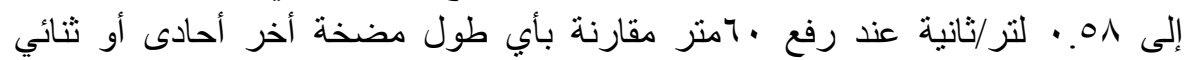
المفعول. الكفاءة الكلية زادت بزيادة طول المضخة حتى طول · مسم، بعد ذلك الزيادة توقفت، زيادة

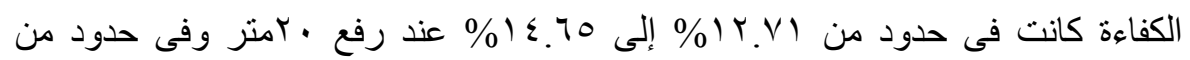

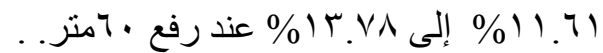
الهو اء المستهلك لرفع منر مكعب ماء وكذلك الطاقة المستهلكة زادت بزيادة الرفع، بينما

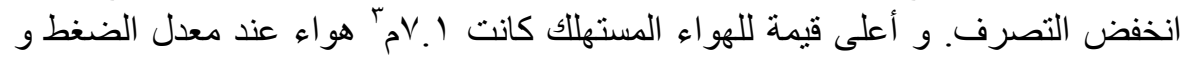

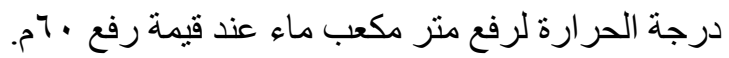

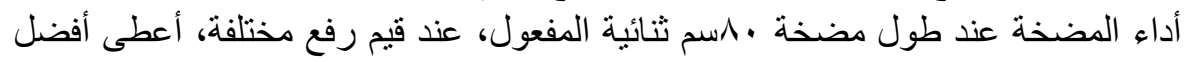

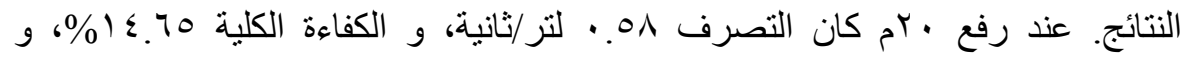

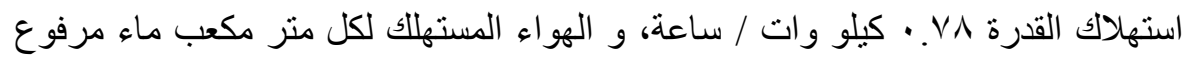

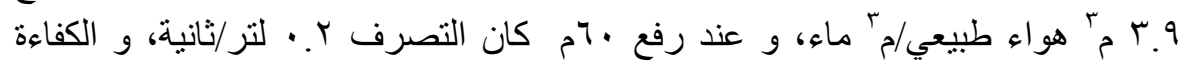

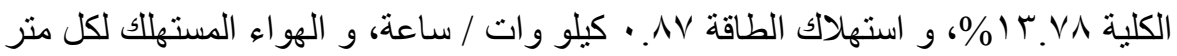
مكعب ماء مرفوع 9.

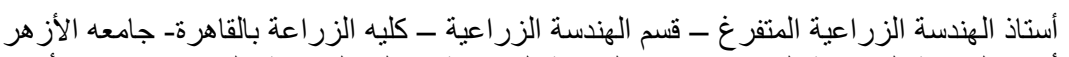

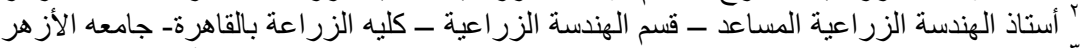

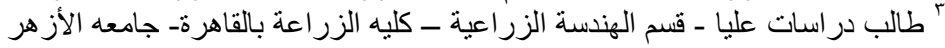

